\title{
MELIGITIMASI TINDAKAN NEGARA BERDASARKAN KEKUASAAN (MACHSTAAT)
}

\author{
Kajian Putusan Nomor 95/B/2017/PT.TUN.JKT
}

\section{LEGITIMATED THE STATE ACTION BASED ON POWER (MACHSTAAT)}

An Analysis of Decision Number 95/B/2017/PT.TUN.JKT

\author{
Vera W. S. Soemarwi \\ Fakultas Hukum Universitas Tarumanagara \\ Kampus I, Jl. Letjen S. Parman No. 1, Jakarta 11450 \\ Email: veras@fh.untar.ac.id atau vwsoemarwi@gmail.com
}

Naskah diterima: 4 Desember 2017; revisi: 21 Agustus 2019; disetujui 22 Agustus 2019

http://dx.doi.org/10.29123/jy.v12i2.294

\section{ABSTRAK}

Artikel ini membahas Putusan Nomor 95/B/2017/ PT.TUN.JKT yang melanggengkan tindakan negara berdasarkan kekuasaan (machtstaat). Objek sengketa dalam perkara a quo adalah Surat Peringatan Ketiga (SP 3) yang diterbitkan oleh Kasatpol PP Jakarta Selatan, yang isinya meminta para penggugat untuk membongkar bangunan rumah miliknya. Dari data tersebut, penulis menemukan rumusan masalah, yaitu: apakah pertimbangan majelis hakim banding dalam merumuskan SP 3 "tidak bertentangan dengan asasasas umum pemerintahan yang baik dan UndangUndang Administrasi Pemerintahan" sudah tepat?; dan apakah pertimbangan hukum dalam putusan a quo dapat memberikan jaminan perlindungan akan hak atas tanah berdasarkan Undang-Undang Pokok Agraria dan Undang-Undang Pengadaan Tanah? Dalam menganalisis putusan a quo, penulis menggunakan metode socio legal science. Hasil analisis penulis, putusan a quo yang mengatakan bahwa "penerbitan SP 3 tidak bertentangan dengan peraturan perundang-undangan dan asas-asas umum pemerintahan yang baik" merupakan sebuah pertimbangan yang tidak tepat. Karena penertiban
\end{abstract}

itu bertentangan dengan asas kepastian hukum, dan bertentangan dengan Undang-Undang Administrasi Pemerintahan, Undang-Undang Pokok Agraria dan Undang-Undang Pengadaan Tanah. Putusan a quo tidak dapat memberikan perlindungan hukum pada para pemilik tanah, karena Undang-Undang Pokok Agraria dan Undang-Undang Pengadaan Tanah memberikan perlindungan hukum kepada masyarakat untuk memiliki tanah.

Kata kunci: pengadaan tanah untuk pembangunan, hak atas tanah, tindakan melawan kewajiban hukum.

\section{ABSTRACT}

This article discusses the Decision of Number 95/B/2017/ PT.TUN.JKT which perpetuates the state actions based on power (machtstaat). The object of the dispute in the a quo case was the Third Warning Letter (SP 3) that issued by Head of the Civil Service Police Unit of South Jakarta (Kasatpol PP Jakarta Selatan), which asked the plaintiffs to demolish their house. From these data, the authors found the formulation of the problem, namely: are the considerations of the appeals panel of judges in 
formulating SP 3 "not contrary to the general principles of good governance and the Government Administration Law" are appropriate?; and whether legalconsiderations in a quo decision can provide guarantees of protection of land rights based on the Basic Agrarian Law and the Land Procurement Law? In analyzing the a quo verdict, the author uses the socio legal science method. The results of the author's analysis, a quo verdict which states that "SP 3 issuance does not conflict with statutory regulations and the general principles of good

\section{PENDAHULUAN}

\section{A. Latar Belakang}

Pada tahun 2007, beberapa wilayah di Jakarta dilanda banjir cukup parah, dan sejak saat itu Pemerintah Republik Indonesia memutuskan untuk memperlebar kali-kali di beberapa wilayah di Indonesia. Kementerian Pekerjaan Umum dan Perumahan Rakyat - Balai Besar Wilayah Sungai Ciliwung Cisadane ditunjuk sebagai pelaksana keputusan itu. Keputusan tersebut dituangkan dalam Rencana Program Pembangunan Jangka Menengah Daerah. Salah satu rencana program itu dikenal dengan normalisasi kali Ciliwung. Dalam proses penentuan program ini, pemerintah pusat belum terlihat mengikutsertakan masyarakat (Soemarwi, 2017b: 236). Tindakan ini bertolak belakang dengan kewajiban hukum pemerintah. Pasal 7 ayat (2) huruff Undang-Undang Nomor 30 Tahun 2014 tentang Administrasi Pemerintahan menyebutkan bahwa pemerintah mempunyai kewajiban untuk "memberikan kesempatan kepada warga masyarakat untuk didengar pendapatnya sebelum membuat keputusan ..."

Untuk mengimplementasikan program normalisasi kali Ciliwung, pemerintah pusat membutuhkan ruang dan tanah guna memperlebar kali dan membangun jalan inspeksi. Dalam rangka governance" is an inaccurate consideration because the regulation is contrary to the principle of legal certainty, and contrary to the Government Administration Law, the Basic Agrarian Law and the Land Procurement Law. A quo verdict cannot provide legal protection to landowners, because, the Basic Agrarian Law and the Land Procurement Law provide legal protection for the community to own land.

Keywords: land acquisition for development, land rights, actions against legal obligations.

mengadopsi program pemerintah pusat menjadi program pemerintah daerah, DPRD Provinsi DKI Jakarta mengubah Peraturan Daerah Khusus Ibukota Jakarta Nomor 6 Tahun 1999 tentang Rencana Tata Ruang Wilayah DKI Jakarta (Perda Nomor 6 Tahun 1999), menjadi Peraturan Daerah Khusus Ibukota Jakarta Nomor 1 Tahun 2012 tentang Rencana Tata Ruang Wilayah 2030 (Perda Nomor 1 Tahun 2012).

Normalisasi kali Ciliwung masuk dalam Perda Nomor 1 Tahun 2012. Konsekuensi dari perubahan Perda Nomor 6 Tahun 1999 menjadi Perda Nomor 1 Tahun 2012, tata ruang di wilayah Bukit Duri menjadi berubah dari berwarna kuning menjadi sebagian warna hijau untuk taman kota, dan sisa ruang digunakan untuk jalan inspeksi. Penyelenggaraan penataan ruang di wilayah Bukit Duri dilakukan oleh pemerintah tanpa melibatkan masyarakat setempat (Gugatan Perwakilan Kelompok Warga Bukit Duri dengan Putusan Nomor 262/PDT.G/2016/PN.JKT.PST jo. Putusan Nomor 262/PDT.G./2016/PN.JKT. PST; dan Soemarwi, 2017b). Mengacu pada Pasal 65 Undang-Undang Nomor 26 Tahun 2007 tentang Penataan Ruang, pemerintah diwajibkan untuk melibatkan masyarakat terdampak dalam penataan ruang di suatu wilayah. Pada kenyataannya masyarakat terdampak belum 
dilibatkan dalam penataan ruang di wilayahnya.

Pemerintah Provinsi DKI Jakarta (Pemda Jakarta) menjabarkan rencana teknis program normalisasi kali Ciliwung dalam Peraturan Gubernur DKI Jakarta Nomor 163 Tahun 2012 tentang Penguasaan Perencanaan/Peruntukan Tanah Bagi Pelaksanaan Pembangunan Untuk Kepentingan Umum Rencana Trace Kali Ciliwung Dari Pintu Air Manggarai-Kampung Melayu (Pergub Nomor 163 Tahun 2012). Pelaksanaan program ini harus mengacu pada Undang-Undang Nomor 2 Tahun 2012 tentang Pengadaan Tanah Bagi Pembangunan untuk Kepentingan Umum (Undang-Undang Pengadaan Tanah).

Pasal 24 Undang-Undang Pengadaan Tanah membatasi jangka waktu pelaksanaan proyek untuk kepentingan umum selama dua tahun dan dapat diperpanjang selama satu tahun. Pembatasan jangka waktu ini sejalan dengan batas waktu berlakunya Pergub Nomor 163 Tahun 2012 (Pasal 3), yaitu selama dua tahun dan berakhir sampai 5 Oktober 2014 (Pasal 3 jo. Pasal 5). Karena proyek ini belum selesai dikerjakan pada tanggal 5 Oktober 2014, maka Gubernur Jakarta memutuskan untuk memperpanjang selama satu tahun melalui Keputusan Gubernur DKI Jakarta Nomor 2181 Tahun 2014 tentang Perpanjangan Penetapan Lokasi Untuk Pelaksanaan Pembangunan Trace Kali Ciliwung Dari Pintu Air Manggarai Sampai Dengan Kampung Melayu (Kepgub Nomor 2181 Tahun 2014).

Diktum Kesatu Kepgub ini menegaskan pembatasan kewenangan Pemda Jakarta dalam melaksanakan pembebasan lahan sampai tanggal 5 Oktober 2015. Setelah lewat tanggal 5 Oktober 2015, Pemda Jakarta sudah tidak punya kewenangan untuk melakukan pembebasan lahan dan melaksanakan program ini (Pasal 15 ayat (2) Undang-Undang Administrasi Pemerintah). Namun kenyataannya sampai bulan Februari 2017, Pemda Jakarta masih melaksanakan tindakan-tindakan faktual di wilayah Bukit Duri RW 10, 11, dan 12.

Pertama, menerbitkan SP 1, 2, dan 3 dengan menggunakantindakan hukum yang berbeda, yaitu Peraturan Daerah DKI Jakarta Nomor 8 Tahun 2007 (Perda Tibum). Kedua, SP ini diterbitkan tanpa memberikan kesempatan kepada warga Bukit Duri untuk didengar pendapatnya sebelum membuat keputusan. Ketiga, menggusur paksa dan menghancurkan rumah dan harta benda milik warga di Bukit Duri (para penggugat). Keempat, mencabut hak kepemilikan atas tanah-tanah warga Bukit Duri (para penggugat) secara sepihak untuk pelaksanaan program yang telah habis masa berlakunya. Kelima, tidak memberikan kompensasi berupa penggantian hak atas tanah dan bangunan seperti yang diamanatkan oleh dokumen perencanaan program, amdal, UndangUndang Pengadaan Tanah, Perpres Nomor 71 Tahun 2012, Pergub Nomor 163 Tahun 2012, dan Kepgub Nomor 2181 Tahun 2014. Keenam, tetap melaksanakan program normalisasi kali Ciliwung meskipun dasar hukum program ini sudah habis masa berlakunya.

Ketiga SP diterbitkan oleh Kepala Satuan Polisi Pamong Praja Kota Administrasi Jakarta Selatan (Kasatpol PP) atas perintah dari Gubernur DKI Jakarta pada tanggal 20 September 2016. Tindakan Gubernur DKI Jakarta Cq. Walikota Jakarta Selatan Cq. Kasatpol PP dalam menerbitkan ketiga SP telah melampaui wewenangnya, maka segala keputusan dan tindakannya menjadi tidak sah (Pasal 18 jo. Pasal 19 ayat (1) Undang-Undang Nomor 30 Tahun 2014). Keenam tindakan faktual yang 
dilakukan oleh Pemda Jakarta menjadi tidak sah karena Pemda Jakarta sudah tidak mempunyai kewenangan.

Dokumen amdal normalisasi mewajibkan pengadaan tanah dilakukan berdasarkan Undang-Undang Pengadaan Tanah. Tahaptahap pelaksanaan yang harus dilalui, yaitu: (a) inventarisasi dan identifikasi penguasaan, pemilikan, penggunaan, dan pemanfaatan tanah; (b) penilaian ganti kerugian; (c) musyawarah penetapan ganti kerugian; (d) pemberian ganti kerugian; dan (e) pelepasan tanah (Pasal 27 s/d 55 Undang-Undang Nomor 2 Tahun 2012 jo. Pasal 49 ayat (1) dan (2) Perpres Nomor 71 Tahun 2012).

Dalam dokumen amdal normalisasi ditentukan tanah yang akan digunakan untuk melebarkan kali Ciliwung, dan membangun jalan inspeksi di pinggir kali adalah tanah-tanah milik masyarakat setempat (para penggugat), dan telah dibangun rumah-rumah permanen dan semi permanen (PUPR - BBWSCC, 2015: 1-32). Dokumen amdal mengakui tanah-tanah bekas milik adat para penggugat yang dimiliki secara turun-temurun. Pengakuan ini dicantumkan dalam pertimbangan hukum majelis hakim tingkat pertama dalam Putusan Nomor 205/G/2016/ PTUN.JKT).

Selama proses persidangan di tingkat pertama, pihak tergugat (Kasatpol PP Jakarta Selatan) mengajukan bukti-bukti surat. Salah satu bukti suratnya adalah Dokumen Amdal, Rencana Pengelolaan Lingkungan (RKL), dan Rencana Pemantauan Lingkungan (RPL). Pengajuan ketiga dokumen tersebut di atas telah membuktikan bahwa tanah-tanah yang digunakan untuk pelaksanaan proyek normalisasi kali Ciliwung merupakan tanah-tanah milik para penggugat. Hak kepemilikan atas tanah para penggugat beragam. Fakta dan bukti ini tidak dipertimbangkan oleh majelis hakim tingkat banding.

Pemda Jakarta telah menginventarisasi dan mengidentifikasi penguasaan, pemilikan, penggunaan, dan pemanfaatan tanah. Bentuk dari kegiatan ini berupa gambar peta bidang dan identifikasi pemilik tanah dan bangunan. Pemda Jakarta tidak melakukan proses selanjutnya seperti: (a) penilaian ganti kerugian, (b) musyawarah penetapan ganti kerugian, dan (c) pemberian ganti rugi.

Pemda Jakarta di luar rencana kerja, menggunakan arbitrary power untuk mencabut hak-hak atas tanah dan tempat tinggal milik para penggugat dengan menggunakan mekanisme Perda Tibum (Soemarwi, 2017b: 237). Setelah SP 3 diterbitkan, tanggal 28, 29, 30 September sampai tanggal 1 dan 3 Oktober 2016, rumah para penggugat dihancurkan, para penggugat digusur, dan tanah milik warga digunakan untuk program normalisasi kali Ciliwung dan membangun jalan inspeksi. Dampak yang ditimbulkan dari penerapan Perda Tibum pada SP 3, para penggugat tidak mendapatkan hak-haknya, yaitu hak atas perumahan, hak atas penggantian yang layak atas tanah dan bangunannya, dan hak atas pekerjaan yang layak.

Permasalahan utama dalam kebijakan Pemda Jakarta ketika melaksanakan proyek pembangunan untuk kepentingan umum berupa menormalisasi kali Ciliwung, mempunyai dua tindakan yang berbeda, yaitu antara tindakan hukum dengan tindakan faktual tidak sama. Tindakan hukum untuk menerbitkan ketiga SP dengan dasar hukum Perda Tibum. Setelah penggusuran, Pemda Jakarta melakukan tindakan 
faktual untuk melaksanakan program normalisasi yang dasar hukumnya sudah habis masa berlakunya.

Dari hasil pemeriksaan setempat yang dilakukan oleh majelis hakim pada tingkat pertama pada tanggal 18 November 2016 disimpulkan, bahwa: (1) para penggugat adalah warga terdampak terbitnya SP 3; (2) para penggugat merupakan korban penggusuran paksa yang melawan hukum; (3) para penggugat adalah pemilik tanah dan bangunan yang digunakan untuk proyek normalisasi kali Ciliwung yang telah kedaluwarsa dan tidak mendapatkan ganti rugi yang layak; (4) para penggugat memiliki kerugian riil dari diterbitkannya objek sengketa (ketiga SP); dan (5) kerugian riil itu berupa hilangnya rumah dan tanah, hilangnya pekerjaan, dan hilangnya fasilitas sosial dan fasilitias umum di Bukit Duri.

Setelah melakukan pemeriksaan setempat dan menimbang bukti-bukti yang diajukan oleh tergugat, majelis hakim tingkat pertama berpendapat bahwa tanah-tanah yang digunakan untuk proyek normalisasi kali Ciliwung merupakan tanah-tanah milik para penggugat yang telah dikuasai secara turun-temurun, dan meskipun proyek normalisasi kali Ciliwung telah habis masa berlakunya, namun kewajiban hukum Pemda Jakarta untuk memberikan ganti rugi atas tanah-tanah dan bangunan milik penggugat tetap harus diberikan.

Majelis hakim dalam Putusan Nomor 205/G/2016/PTUN.JKT berpendapat bahwa penerbitan SP 3 bertentangan dengan asas-asas umum pemerintahan yang baik, khususnya asas kepastian hukum, dan bertentangan dengan Undang-Undang Pengadaan Tanah. Pendapat majelis hakim tersebut telah tepat. Majelis hakim menimbang objek sengeta SP 3 diterbitkan dengan dasar hukum yang berbeda dengan tindakan faktual. Wewenang untuk melaksanakan proyek normalisasi ini sudah kedaluwarsa. Bukti-bukti yang diajukan dalam sidang digelar di tingkat pertama (PTUN Jakarta) dan pengakuan tergugat membenarkan perbedaan tindakan ini.

Berdasarkan fakta-fakta di atas dan pengakuan tergugat di persidangan PTUN Jakarta, pertimbangan majelis hakim PTTUN bertentangan dengan pertimbangan majelis hakim PTUN. Pendapat majelis hakim dalam Putusan Nomor 95/B/2017/PT.TUN.JKT yang akan dikaji, khususnya dalam menimbang: (1) alat-alat bukti yang diajukan oleh para penggugat/terbanding ternyata tidak ada bukti berupa Sertifikat Hak Milik atas nama para penggugat/terbanding; (2) oleh karena itu majelis hakim banding berpendapat tindakan tergugat untuk melakukan penertiban dan menghancurkan rumah dan bangunan berdiri di bantaran kali Ciliwung sudah tepat dilakukan penertiban; (3) selanjutnya majelis hakim banding mempertimbangkan bahwa "penerbitan objek sengketa tidak bertentangan dengan peraturan perundang-undangan dan juga tidak bertentangan dengan asas-asas umum pemerintahan yang baik; (4) kesimpulan akhir bahwa majelis hakim banding harus menolak gugatan ini.

Putusan a quo akan dikaji oleh penulis dengan menggunakan pendekatan Hukum Administrasi Pemerintahan, Hukum Pengadaan Tanah, Hukum Agraria (Undang-Undang Nomor 5 Tahun 1960 tentang Peraturan Dasar PokokPokok Agraria). Guna melengkapi proses penelitian ini, peneliti menggunakan pendekatan sosial dengan cara bertanya pada para korban penggusuran paksa, bagaimana pendapat dan pandangannya terhadap putusan a quo. 


\section{B. Rumusan Masalah}

1. Apakah pertimbangan majelis hakim banding dalam merumuskan SP 3 "tidak bertentangan dengan asas-asas umum pemerintahan yang baik dan UndangUndang Administrasi Pemerintahan" sudah tepat?

2. Apakah pertimbangan hukum dalam putusan a quo dapat memberikan jaminan perlindungan akan hak atas tanah berdasarkan Undang-Undang Pokok Agraria dan Undang-Undang Pengadaan Tanah?

\section{Tujuan dan Kegunaan}

Tujuan konkret yang diharapkan oleh penulis, agar Komisi Yudisial dapat membuat panduan dan pedoman bagi para hakim dalam membuat pertimbangan hukum yang bersumber pada peraturan perundang-undangan. Karena ajudikasi di pengadilan merupakan pintu bagi para korban untuk mencari keadilan yang berbasiskan pada kebenaran. Oleh karena itu proses pemeriksaan perkara harus dilakukan dengan sistem penemuan hukum yang berdasarkan pada peraturan perundangundangan dan sumber-sumber hukum lainnya. Bila hal ini dilanggar, maka putusan pengadilan akan mencederai rasa keadilan bagi korban. Banyaknya putusan pengadilan tinggi yang tidak mempunyai standar yang jelas dan sistematika baku dalam putusan, contohnya putusan a quo. Sehingga banyak putusan pengadilan yang tidak mengikuti prosedur penemuan hukum. Hal ini berdampak pada penyimpangan prinsip keadilan, kemanfaatan, dan kepastian hukum dalam putusannya, termasuk putusan $a$ quo.
Dalam melakukan penelitian ini penulis berharap agar Mahkamah Agung dan Komisi Yudisial dapat membuat peraturan mengenai tata cara perumusan atau penemuan hukum dalam proses mengonstatir, meng-kwalifisir, dan mengkonstituir, serta menetapkan sistematika putusan hakim yang baku. Sehingga dalam setiap putusan majelis hakim ada kepastian hukum. Di samping itu kegunaan bagi lawyer, akademisi, dan para pencari keadilan mendapatkan manfaat dan kepastian hukum dalam setiap perkaranya, karena putusan hakim yang dibuat mempunyai standar dan sistematika yang baku. Putusan hakim wajib untuk mencantumkan dasar hukum dalam setiap pertimbangannya. Kegunaan penelitian ini bagi para pencari keadilan dan para pembaca lainnya, dapat mengetahui bahwa tanah-tanah yang tidak bersertifikat pun dilindungi oleh hukum agraria di Indonesia. Penerbitan SP 3 bukan merupakan produk hukum yang selalu benar dan berdasarkan pada hukum. Penerbitan SP 3 diwajibkan oleh hukum administrasi pemerintahan untuk memenuhi standar tata kelola pemerintahan yang baik.

\section{Tinjauan Pustaka}

Variabel yang digunakan dalam penelitian ini adalah: (1) wewenang pemerintah dalam hal ini Pemda DKI Jakarta; (2) keputusan administrasi pemerintahan atau tindakan hukum; (3) tindakan administrasi pemerintahan atau tindakan konkret/ faktual; (4) kepastian hukum; dan (5) asas legalitas. Setiap wewenang pemerintah dibatasi oleh isi/materi (materiale), wilayah/ruang (locus), dan waktu (tempus). Apabila salah satu dari ketiga pembatasan itu tidak terpenuhi, maka pemerintah akan kehilangan kewenangannya untuk menerbitkan sebuah keputusan dan tindakan administrasi. Artinya apabila tindakan 
dan keputusan administrasi di luar batas-batas tersebut, maka tindakan pemerintah dapat dikategorikan sebagai tindakan pemerintah tanpa wewenang atau cacat wewenang.

Hakim (2011: 103-130) menerjemahkan wewenang pemerintah memberikan kemampuan untuk melakukan tindakan hukum tertentu (tindakan yang dimaksud untuk menimbulkan akibat hukum, mencakup timbul dan lenyapnya akibat hukum tertentu). Kewenangan negara untuk melaksanakan kewajiban sesuai dengan instrumen yang ada agar tercapai keadilan dan kesejahteraan bersama (Mahfud MD, 2006; Erwiningsih, 2009). Pengertian asas legalitas menurut Wijk (1984: 34) sebagai berikut: "wetmatigheid van bestuur: de uitvoerende macht bezit uitsluitend die bevoegdheden welke haar uitdrukkelijk door de grondwet of door een andere wet zijn toegeken" (legalitas administrasi pemerintahan: kekuasaan administrasi pemerintahan hanya mengikat dan memberikan kekuatan yang secara tegas diberikan kepadanya berdasarkan pada undang-undang dasar dan/atau peraturan perundang-undangan lainnya).

Indroharto (1993: 70) merumuskan asas legalitas adalah “...tanpa ada dasar wewenang yang diberikan oleh suatu peraturan perundangundangan yang berlaku, maka segala macam 'tindakan' aparat pemerintah itu tidak akan memiliki wewenang yang dapat memengaruhi atau mengubah keadaan atau posisi hukum warga masyarakatnya." Menurut Suseno (1987) dan Erwiningsih (2009), power diterjemahkan sebagai kekuasaan, sedangkan authority diterjemahkan sebagai wewenang.

Kekuasaan, kekuatan, dan wewenang berkaitan erat dengan paksaan yang antara lain terwujud dalam sanksi hukum. Wewenang yang dimiliki oleh aparatur negara harus dijalankan menurut hukum. Wewenang untuk mengatur dimiliki oleh negara dalam lingkup hukum publik. Negara dapat melakukan hubungan hukum seperti benda-benda perseorangan. Hubungan hukum negara dengan tanah masuk kategori benda atau tanah yang digunakan bagi umum seperti jalan umum milik negara dan tanah yang digunakan untuk kepentingan dinas umum seperti bangunan perkantoran pemerintah, maka tanah itu menjadi milik negara. Definisi "milik negara" tidak saja berdasar wewenang yang ditentukan menurut hukum, tetapi meliputi kompentensi dengan kemampuan memikul hak dan kewajiban. Negara dipandang sebagai subjek hukum yang sama dengan warga negara (Erwiningsih, 2009).

Asas legalitas sangat erat kaitannya dengan konsep dasar bahwa Indonesia merupakan negara berdasarkan pada hukum (Pasal 1 ayat (3) UUD NRI 1945). Menurut Stahl, negara hukum harus mengandung empat unsur utama, yaitu: (1) adanya jaminan terhadap hak asasi manusia; (2) adanya pembagian kekuasaan; (3) pemerintah haruslah berdasarkan pada peraturan perundangundangan; dan (4) adanya peradilan administrasi (Sirajuddin \& Winardi, 2015: 25).

Empat elemen penting dalam asas legalitas yang harus dimiliki dalam setiap keputusan hukum pemerintahan dalam arti luas, yaitu: (1) pemerintah dalam menjalankan kekuasaannya selalu berdasarkan pada hukum; (2) setiap kebijakan dan tindakannya harus memberikan perlindungan hak asasi warga negaranya (hak asasi manusia); (3) pembagian kekuasaan negara yang jelas adil dan konsisten; (4) perlindungan hukum dari badan-badan peradilan terhadap tindakan pemerintah (Sugiono \& Husni MD, 2000). 
Dari rumusan teori-teori hukum di atas, penulis merumuskan teori yang disampaikan di bawah ini dalam bentuk skema. Rumusan ini diambil dari hasil penelitian proses pengadaan tanah yang dilakukan oleh Pemda Jakarta dalam proyek normalisasi kali Ciliwung. Untuk melengkapi penelitian tersebut, penulis melakukan proses adjudikasi ke Pengadilan Tata Usaha Negara dan Pengadilan Negeri Jakarta Pusat. Proses adjudikasi ini dilakukan oleh penulis untuk membuktikan teori yang penulis sampaikan di bawah ini:

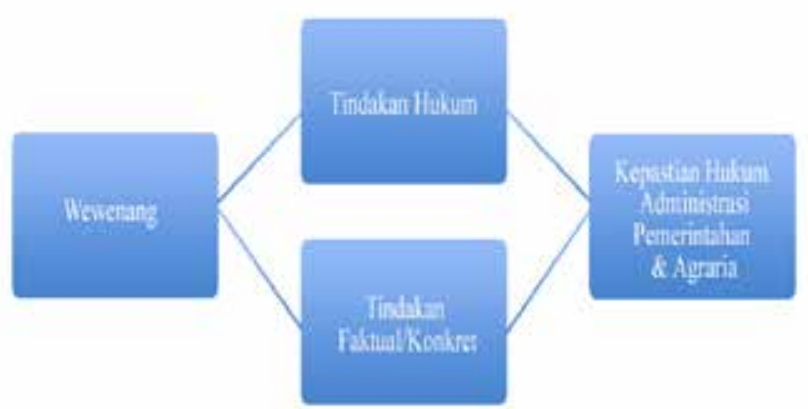

Gambar 1. Good Governance

Sumber: Soemarwi, 2017b

Penjelasan skema di atas adalah wewenang yang dimiliki oleh pejabat administrasi pemerintahan harus berdasarkan dari peraturan perundang-undangan yang berlaku. Peraturan perundang-undangan yang berlaku akan membatasi wewenang berdasarkan pada lokasi, jangka waktu, tugas atau objek yang spesifik, subjek pelaksana yang ditunjuk untuk melakukan wewenang tersebut.

Wewenang yang diberikan kepada pejabat pemerintah untuk membuat kebijakan hukum dan melaksanakan kebijakan hukum itu dibatasi oleh peraturan perundang-undangan yang membentuknya. Kebijakan hukum harus sesuai dengan tindakan konkret yang dilakukan oleh pejabat pemerintah, sehingga rangkaian tindakan hukum dan tindakan konkret akan menimbulkan kepastian hukum.

\section{METODE}

Penulis dalam mengkaji putusan a quo menggunakan metode socio legal rea. Secara umum peneliti menggunakan pendekatan hukum dan pandangan masyarakat terhadap hukum itu. Bagaimana putusan a quo itu diterapkan, diberlakukan bagi para terbanding/penggugat, dan apa pandangan mereka terhadap putusan $a$ quo bagi mereka. Pertimbangan majelis hakim banding dikaji dengan menggunakan pendekatan hukum dan menerapkan teori-teori hukum dan prinsip-prinsip dasar dalam hukum administrasi pemerintahan, hukum pengadaan tanah, hukum agraria, serta prinsip-prinsip dan teori negara hukum.

Putusan a quo dikaji oleh penulis dengan menggunakan data-data pembanding yang diperoleh dari hasil wawancara antara penulis dengan para penggugat dan tergugat sejak 2015-2017. Untuk mendukung dan memperoleh data-data empiris, penulis mengikuti proses pemeriksaan di pengadilan tingkat pertama, dan mewawancarai warga lainnya yang tinggal di Bukit Duri dan para penggugat. Penulis memperoleh data-data lainnya dari Kementerian Lingkungan Hidup dan Bappenas.

Penulis menggunakan data primer dan data sekunder yang diperoleh dari Pemerintah Provinsi DKI Jakarta, Balai Besar Wilayah Sungai Ciliwung Cisadane, Pemerintah Kota Administrasi Jakarta Selatan, dan warga Bukit Duri RT. 06/RW. 12, Kelurahan Bukit Duri, Tebet, Jakarta Selatan. Data primer dan sekunder yang digunakan oleh penulis telah diperiksa oleh majelis hakim pada tingkat pertama. 


\section{HASIL DAN PEMBAHASAN}

A. Pertimbangan Majelis Hakim dalam Putusan Nomor 95/B/2017/PT.TUN.JKT

Putusan a quo bertentangan dengan Pasal 7 ayat (2) huruf f Undang-Undang Nomor 30 Tahun 2014 (Undang-Undang Administrasi Pemerintahan) dalam menilai bahwa bukti T.4, T.5, dan T.6 yang berupa undangan dan daftar hadir sosialisasi relokasi warga Bukit Duri sekitar kali Ciliwung yang diadakan pada tanggal 15 Maret 2016, tanggal 21 April 2016, dan tanggal 2 Mei 2016, menurut majelis hakim banding sebelum diterbitkan objek sengketa tersebut telah disosialisasikan kepada warga Bukit Duri sekitar kali Ciliwung, termasuk para penggugat/ terbanding, sehingga tidak bertentangan dengan asas-asas umum pemerintahan yang baik.

Penilaian majelis hakim terhadap bukti T.4, T.5, dan T.6 dalam putusan a quo tidak meneliti apakah Pemda Jakarta mempunyai wewenang untuk membuat keputusan hukum berupa penerbitan SP 3. Ketika Pemda Jakarta menerbitkan bukti-bukti tersebut, Pemda Jakarta sudah tidak mempunyai wewenang untuk menerbitkan sebuah keputusan hukum maupun tindakan hukum normalisasi dan penggusuran paksa, karena wewenang yang dimiliki oleh Pemda Jakarta sudah kedaluwarsa atau habis masa berlaku kewenangannya.

Bila mengacu pada dasar hukum proyek normalisasi kali Ciliwung, yaitu Pergub Nomor 163 Tahun 2012 jo. Kepgub Nomor 2181 Tahun 2014 telah habis masa berlakunya pada tanggal 5 Oktober 2015. Berdasarkan kedua aturan tersebut, kewenangan Pemda Jakarta dalam melaksanakan proyek ini dibatasi oleh: (1) waktu pelaksanaan kewenangan; dan (2) bagaimana kewenangan ini harus dijalankan.
Materi kedua peraturan itu memberikan kewenangan kepada Pemda Jakarta untuk melaksanakan pembebasan lahan berdasarkan Undang-Undang Pengadaan Tanah. Kedua peraturan ini membatasi kewenangan Pemda Jakarta untuk melaksanakan pembebasan lahan di wilayah Bukit Duri sampai 5 Oktober 2015. Setelah lewat tanggal 5 Oktober 2015, Pemda Jakarta sudah tidak punya kewenangan melaksanakan tindakan konkret/faktual untuk melaksanakan program ini, karena dasar hukum yang memberikan kewenangannya telah habis masa berlakunya (Pasal 15 ayat (2) UndangUndang Administrasi Pemerintahan). Namun kenyataannya sampai bulan Februari 2017, Pemda Jakarta masih melakukan tindakan konkret/faktual di atas.

Tindakan Pemda Jakarta ini jelas bertentangan dengan kewajiban hukumnya yang diatur dalam Pasal 15 ayat (2); Pasal 18 ayat (1) huruf a jo. huruf c Undang-Undang Nomor 30 Tahun 2014. Apabila merujuk pada Pasal 19 ayat (1) Undang-Undang Nomor 30 Tahun 2014, akibat hukum dari tindakan Pemda Jakarta ini menjadi tidak sah. Yang dimaksud dengan "tidak sah" adalah keputusan hukum berupa penerbitan ketiga SP dan tindakan konkret/faktual lainnya yang dilakukan oleh Pemda Jakarta tidak berwenang, sehingga dianggap tidak pernah ada atau dikembalikan pada keadaan semula sebelum penerbitan ketiga SP.

Tindakan konkret/faktual yang dilakukan dengan segala akibat hukum yang ditimbulkan dianggap tidak pernah ada (Penjelasan Pasal 19 ayat (1) Undang-Undang Administrasi Pemerintahan). Pemda Jakarta telah positif melakukan perbuatan melawan hukum (Putusan Nomor 262/PDT.G/2016/PN.Jkt.Pst). Majelis hakim banding menyampingkan fakta yang 
diperoleh dari pemeriksaan setempat. Bahwa dari hasil pemeriksaan setempat, tindakan konkret Pemda Jakarta melaksanakan program normalisasi yang telah kedaluwarsa sejak 5 Oktober 2015. Pelaksanaan kelima tindakan konkret itu, menjadi tidak sah menurut hukum administrasi pemerintahan.

Pasal 15 ayat (2) Undang-Undang Administrasi Pemerintahan menegaskan pejabat pemerintah tidak dibenarkan untuk mengambil keputusan maupun tindakan konkret apabila jangka waktu kewenangan yang ditetapkan dalam keputusan dasar telah berakhir. Kelima tindakan Pemda Jakarta ini dikategorikan melampaui wewenangnya, karena melampaui batas waktu berlakunya wewenang dan bertentangan dengan ketentuan peraturan perundang-undangan (Pasal 18 ayat (1) huruf a dan huruf c).

Penulis mengkaji pertimbangan di atas dengan melihat pada pengertian administrasi negara yang bersifat kombinatif (verzamelterm), yaitu: (1) administrasi sebagai sebuah organisasi; dan (2) administrasi yang secara konstan mengejar tujuan yang telah ditetapkan oleh undang-undang secara " $d$ wingend recht" (hukum yang memaksa).

Wijk(1984: 1) dalambukunya Hoofdstukken van administratief recht, mengatakan: "hukum administrasi, hukum tata pemerintahan, semuanya menyangkut administratie, bestuur, dan besturen. Secara umum dapat dikatakan: hukum administrasi merupakan instrumen yuridis bagi penguasa untuk secara aktif terlibat dengan masyarakat. Pada sisi lain hukum administrasi merupakan hukum yang memungkinkan anggota masyarakat memengaruhi penguasa dan memberikan perlindungan terhadap penguasa" (Hadjon et al., 2015).
Ditinjau dari aspek wewenang adalah hak penyelenggara negara untuk melakukan sebuah tindakan dan keputusan hukum yang dapat menimbulkan akibat hukum. Hak untuk melaksanakan kewenangannya harus berdasarkan peraturan perundang-undangan dan asas-asas umum pemerintahan yang baik (Pasal 6 ayat (2) huruf a Undang-Undang Administrasi Pemerintahan). Wewenang yang sah akan menimbulkan kewenangan. Kewenangan merupakan hak dan kekuasaan yang timbul karena diatur dalam peraturan perundang-undangan, kepatutan, keajekan, dan keadilan. Kewenangan itu dimiliki oleh pejabat pemerintah apabila peraturan dasar mengaturnya secara tegas dan terinci mengenai kapan (tenggang waktu wewenang), bagaimana (cakupan bidang atau materi wewenang), dan di wilayah mana kewenangan itu bisa dijalankan (Pasal 15 ayat (1) Undang-Undang Administrasi Pemerintahan).

Penerbitan SP 3 ditinjau dari cakupan bidang SP 3 merupakan pelaksanaan proyek normalisasi kali Ciliwung, maka penerbitan SP 3 harus dikaji dengan tenggang waktu wewenang itu bisa dilakukan. Melihat pada tenggang waktu pelaksanaan wewenang itu, Pemda Jakarta sudah tidak mempunyai wewenang untuk menerbitkan SP 3 dan melakukan penggusuran paksa di wilayah Bukit Duri. Penerbitan ketiga SP merupakan tindakan hukumyang didasarkan pada Perda Tibum. Pemda Jakarta melakukan tindakan konkret berupa pengambilalihan secara paksa tanah milik para penggugat untuk pelaksanaan proyek normalisasi kali Ciliwung di wilayah penerbitan ketiga SP, yaitu Bukit Duri. Sedangkan tindakan hukum ketiga SP itu berbeda dengan dasar hukum yang digunakan untuk memutuskan penerbitan ketiga SP.

Merujuk pada unsur bagaimana kewenangan itu harus dijalankan, maka tindakan 
Pemda Jakarta dalam melakukan akibat hukum dari pelaksanaan penerbitan ketiga SP melanggar kewenangan yang telah diberikan. Pelanggaran kewenangan ini berdampak pada tidak sahnya tindakan konkret Pemda Jakarta. Tindakan Pemda Jakarta dalam hukum administrasi pemerintahan termasuk dalam kategori mencampuradukkan wewenang, karena keputusan hukum yang dibuat bertujuan untuk melakukan penertiban Perda Tibum. Sedangkan tindakan konkret Pemda Jakarta untuk melakukan program normalisasi kali Ciliwung. Tindakan hukum Pemda Jakarta tidak sesuai dengan tindakan faktualnya.

Putusan a quo belum meninjau apakah penerbitan ketiga SP itu sudah sesuai dengan prosedur administrasi pemerintahan berdasarkan hukum administrasi pemerintahan. Dalam mengkaji pertimbangan di atas, penulis menggunakan definisi kekuasaan dari Weber (2019). Otoritas menurut Weber "membuat orang lain mematuhi perintah dengan isi tertentu." Weber berpendapat kekuasaan tanpa otoritas tidak banyak artinya. Seluruh organ-organ negara dapat berfungsi apabila ada otoritas di tangan kekuasaan negara. Oleh karenanya otoritas merupakan bentuk kekuasaan yang khas.

Mengkaji bukti undangan sosialisasi dalam putusan a quo adalah sosialisasi mengenai pelaksanaan proyek normalisasi kali Ciliwung di Bukit Duri. Pemda Jakarta belum pernah mensosialisasikan objek sengketa (SP 3), yaitu penertiban dengan dasar hukum Perda Tibum. Keterangan ini diperoleh dari saksi penggugat dan saksi tergugat yang mengatakan Pemda Jakarta dan Balai Besar Wilayah Sungai Ciliwung Cisadane menjelaskan mengenai program normalisasi kali Ciliwung yang akan dilaksanakan di Bukit Duri. Para penggugat diminta untuk segera menghancurkan rumah mereka dan segera pindah ke rumah susun sewa di Rawa Bebek (Soemarwi, 2017a). Pemda Jakarta mengatakan proyek ini bukan proyek pembangunan untuk kepentingan umum. Pemda Jakarta mengatakan para penggugat tidak akan mendapatkan ganti rugi. Para penggugat menolak untuk menghancurkan rumah mereka dan menolak untuk pindah ke rumah susun sewa Rawa Bebek.

Para penggugat tidak pernah diberitahu akan terbit ketiga SP dan rencana penggusuran. Penerbitan ketiga SP dengan dasar hukum Perda Tibum ini bertentangan dengan Pasal 7 ayat (2) huruf f Undang-Undang Nomor 30 Tahun 2017, karena para penggugat tidak pernah diberi kesempatan untuk didengar pendapatnya sebelum Pemda Jakarta menerbitkan ketiga SP ini. Kewajiban Pemda Jakarta untuk mengajak partisipasi para penggugat sebagai warga terdampak merupakan kewajiban hukum Pemda Jakarta yang harus dipenuhi (Soemarwi, 2017a: 234). Ketiga SP ini tidak mengatakan bahwa di lokasi rumah para penggugat akan dibangun proyek normalisasi. Pada kenyataannya di lokasi yang sama digunakan untuk pembangunan proyek normalisasi.

\section{Materi Undang-Undang Administrasi}

Pemerintahan telah memberikan kepastian dan perlindungan hukum kepada para penggugat atas tindakan sewenang-wenang aparat pemerintah. Merujuk pada undang-undang ini, tindakan hukum Pemda Jakarta yang menerbitkan SP 3 menjadi tidak sah. Akibat dari tindakan yang tidak sah maka Pemda Jakarta berkewajiban untuk mengembalikan keadaan seperti sebelum keputusan dan tindakan itu dilakukan. Penggusuran, penghancuran rumahrumah, dan pengambilalihan secara paksa tanah-tanah milik para penggugat telah terjadi. 
Tanah-tanah para penggugat telah digunakan untuk membangun jalan inspeksi proyek ini. Pemda Jakarta mempunyai kewajiban hukum untuk mengembalikan seperti keadaan semula dan memberikan kompensasi kerugian atas kehilangan rumah, tanah, pekerjaan, dan bendabenda lainnya.

Fakta-fakta hukum, bukti, keterangan saksi, keterangan ahli, dan pemeriksaan setempat mendasari pertimbangan majelis hakim di tingkat pertama dalam memutuskan Putusan Nomor 205/G/2016/PTUN.JKT. Majelis hakim tingkat pertama memerintahkan kepada Kasatpol PP untuk membatalkan SP 3 dan memberikan ganti rugi kepada para penggugat. Meskipun dasar hukum program normalisasi kali Ciliwung telah habis masa berlakunya, kewajiban Pemda Jakarta untuk memberikan ganti rugi atas tanah dan bangunan kepada para penggugat tetap ada, karena fakta kerugian akan kehilangan rumah dan tanah milik para penggugat telah terjadi.

Putusan a quo dalam menimbang bukti undangan sosialisasi tidak melihat pada bukti lainnya berupa materi yang disampaikan dalam sosialisasi itu. Putusan a quo mengabaikan prinsip utama dalam hukum administrasi pemerintahan bahwa tindakan hukum harus sama dengan tindakan konkret. Fakta yang dilakukan dalam kasus ini bahwa Pemda Jakarta menggunakan tindakan hukum untuk menerbitkan SP 3 berbeda dengan tindakan konkret/faktual di lapangan.

Putusan a quo mengabaikan fakta penting dan mendasar bahwa Pemda Jakarta sudah tidak mempunyai wewenang untuk melaksanakan proyek ini. Pemda Jakarta sudah tidak mempunyai kekuatan untuk membuat keputusan hukum berupa penerbitan ketiga SP, dan dilarang untuk melakukan tindakan konkret/faktual berupa pengambilalihan hak milik atas tanah secara paksa dan melawan hukum, menghancurkan rumah-rumah para penggugat, dan menggusur paksa para penggugat.

Pengabaian fakta penting ini dalam putusan a quo berdampak pada ketidakpastian hukum administrasi pemerintahan dan pelanggaran asas legalitas (Pasal 5 huruf a Undang-Undang Noomor 30 Tahun 2014). Putusan ini berdampak pada ketidakpastian hukum administrasi pemerintahan, karena Undang-Undang Administrasi Pemerintahan jelas mengatur pembatasan kewenangan ditetapkan berdasarkan pada masa berlakunya suatu keputusan. Dengan berakhirnya masa berlaku keputusan, maka berakhir pula kewenangan yang dimilikinya. Putusan a quo mengabaikan fakta bahwa Pergub Nomor 163 Tahun 2012 jo. Kepgub Nomor 2181 Tahun 2014 telah kedaluwarsa sejak 5 Oktober 2015. Pemda Jakarta tetap melaksanakan kewenangannya yang timbul dari dua peraturan yang sudah kedaluwarsa.

Asas legalitas dalam Undang-Undang Administrasi Pemerintahan merupakan asas yang terpenting dalam penyelenggaraan administrasi pemerintahan. Seluruh penyelenggaraan administrasi pemerintahan harus mengedepankan dasar hukum dalam setiap keputusannya. Keputusan hukum harus sesuai dengan tindakan faktual/tindakan konkret yang dilakukan oleh pejabat pemerintahan (Penjelasan Pasal 5 huruf a).

Bab XA, Pasal 28 UUD NRI 1945 telah memberikan jaminan perlindungan hak asasi manusia bagi setiap warga negara. Merujuk pada teori yang dikemukakan oleh John Locke mengenai teori kontrak sosial, bahwa negara selaku penguasa tidak dapat mengambil atau 
merampas hak asasi manusia. Diaturnya hak asasi manusia ke dalam konstitusi merupakan jaminan bahwa konstitusi merupakan hukum dasar yang tertinggi yang akan berakibat fatal bagi penguasa yang melanggar hak asasi warga negaranya (Humah, 2007: 63-71).

Putusan a quo mengabaikan prinsip negara berdasarkan pada hukum (rule of law). Mengutip pendapat Robert von Mohl (Azhary, 1995: 4648) mengenai prinsip negara hukum, "negara hukum harus dibentuk dengan memperhatikan aspek materi dari hukum dan undang-undangnya. Hukum harus membatasi kekuasaan negara yang absolut tetapi juga adanya jaminan hukum akan hak-hak asasi warga negaranya."

Penulis melihat pola-pola kasus penggusuran dengan menggunakan tindakan hukum berupa Perda Tibum, pasca penertiban, Pemda Jakarta melakukan tindakan konkret yang berbeda dengan tindakan hukum. Menurut Weber tindakan ini telah membentuk tradisi atau kebiasaan yang buruk dalam praktik tata pemerintahan. Warga terdampak penggusuran mempercayai tindakan aparat pemerintah dan penegak hukum sebagai penguasa yang memiliki kharisma. Warga terdampak penertiban Perda Tibum mempercayainya terhadap sistem norma yang formal sebagai sebuah tindakan dengan dasar legalitas yang sah.

Merujuk definisi negara menurut Weber (Syafiie, Tandjung \& Modeong, 1999), "negara adalah suatu masyarakat yang mempunyai monopoli dalam penggunaan kekerasan fisik secara sah dalam suatu wilayah." Putusan a quo melegitimasi penggunaan kekuasaan negara untuk melakukan kekerasan fisik secara sah. Ciri-ciri suatu Negara adalah: (1) pelaksanaan suatu kekuasaan; (2) kepada bangsa tertentu; (3) di suatu wilayah; (4) kekuasaan itu ada dalam bentuk 'lembaga-lembaga negara'; ... atau "pelaksanaan kekuasaan dalam arti menciptakan dan memelihara suatu ketertiban tertentu dalam kenyataan."

Putusan a quo telah melegitimasi kekuasaan negara dengan menggunakan perangkat daerah, perangkat keamanan seperti kepolisian dan tentara untuk menciptakan kekuatan yang absolut demi pencapaian target pembangunan fisik kota (developmentalist) tanpa mempertimbangkan hak ekonomi, hak sosial, dan martabat warga terdampak. Penulis tidak sependapat dengan definisi negara dari Weber. Namun definisi negara dari Weber tepat digunakan untuk menjelaskan tindakan-tindakan Pemda Jakarta yang dilegitimasi oleh majelis hakim dalam putusan a quo.

\section{B. Pertimbangan Majelis Hakim Putusan A Quo dalam Jaminan Perlindungan Hak Atas Tanah Berdasarkan Undang- Undang Pokok Agraria dan Undang- Undang Pengadaan Tanah}

Putusan a quo tidak memberikan jaminan perlindungan hak atas tanah, karena putusan a quo telah bertentangan dengan Buku Kedua Undang-Undang Pokok Agraria Pasal II ayat (1) jo. Undang-Undang Pengadaan Tanah jo. Pasal 24 Peraturan Presiden Nomor 71 Tahun 2012 tentang Penyelenggaraan Pengadaan Tanah Bagi Pembangunan Untuk Kepentingan Umum (Perpres Nomor 71 Tahun 2012).

Pertimbangan majelis hakim dalam Putusan Nomor 95/B/2017/PT.TUN.JKT tidak tepat dalam menilai bahwa "alat-alat bukti yang diajukan oleh para penggugat/terbanding ternyata tidak ada bukti berupa Sertifikat Hak Milik atas 
nama para penggugat/terbanding dan karenanya rumah dan bangunan berdiri di bantaran kali Ciliwung, menurut majelis hakim banding sudah tepat dilakukan penertiban."

Pertimbangan ini lebih menitikberatkan pada ada tidaknya sertifikat hak atas tanah sebagai tanda bukti hak atas tanah para penggugat. Putusan a quo ini tidak dilandasi oleh dasar hukum yang dapat memperkuat argumentasi majelis hakim banding. Bahkan pertimbangan hukumnya bertentangan dengan Undang-Undang Pokok Agraria, Undang-Undang Pengadaan Tanah dan Pasal 24 Perpres Nomor 71 Tahun 2012.

Pertimbangan ini telah mencederai rasa keadilan yang tumbuh dalam masyarakat. Pertimbangan ini tidak memberikan manfaat bagi negara dan masyarakat. Pertimbangan ini telah menimbulkan ketidakpastian dalam hukum pertanahan dan hukum pengadaan tanah bagi kepentingan umum. Pertimbangan ini tidak melihat pada fakta sosial dan ekonomi para penggugat. Putusan a quo telah keliru dalam menilai objek gugatan. Objek gugatan adalah SP, dan bukan sengketa tanah berdasarkan sertifikat tanah.

Dalam kasus penggusuran paksa untuk pelaksanaan program normalisasi kali Ciliwung menerapkan dua kelompok peraturan perundangundangan yang berbeda. Kluster pertama pemberlakuan Perda Tibum sebagai dasar hukum penerbitan SP 3. Kluster kedua pemberlakuan pembebasan lahan berdasarkan Undang-Undang Pengadaan Tanah dan Perpres Nomor 71 Tahun 2012. Kedua kelompok hukum ini memiliki karakter dan tata cara yang berbeda, maka tidak bisa diterapkan bersamaan dalam satu kasus penggusuran paksa seperti di wilayah Bukit Duri dalam kasus a quo.
Prinsip yang diterapkan dalam Perda Tibum adalah penertiban. Penertiban berdasarkan Perda Tibum tidak melihat dasar kepemilikan hak atas tanah warga yang akan ditertibkan. Dalam Perda Tibum, Pemda Jakarta diberi kewenangan mengadili (yudikatif) secara sepihak dalam menilai apakah warga ini melanggar Perda Tibum atau tidak. Perda Tibum diterapkan karena dianggap oleh Pemda Jakarta ada pelanggaran terhadap pasal-pasal dalam Perda itu. Penertiban berdasarkan Perda Tibum tidak menimbulkan kewajiban hukum pada Pemda Jakarta untuk memberikan ganti rugi terhadap korban penertiban. Karena adanya pelanggaran perda ini, maka Pemda Jakarta mempunyai wewenang secara sepihak untuk melakukan penertiban bagi para pelanggar Perda.

Undang-Undang Pengadaan Tanah dan Perpres Nomor 71 Tahun 2012, memiliki tata cara yang sangat berbeda dengan Perda Tibum. Prinsip yang dipegang teguh dalam UndangUndang Pengadaan Tanah adalah kemampuan ekonomi warga terdampak tidak menurun, atau dengan kata lain warga tidak boleh menjadi tidak mampu secara ekonomi ('miskin'). UndangUndang Pengadaan Tanah dan Perpres Nomor 71 Tahun 2012 mengakui kepemilikan tanah para warga baik de jure maupun de facto.

Penjelasan Pasal 40 Undang-Undang Pengadaan Tanah jo. Pasal 17 ayat (2) Perpres Nomor 71 Tahun 2012 membuat beberapa kriteria para pemegang hak atas tanah yang berhak mendapatkan penggantian yang layak adalah: (1) pemegang hak atas tanah; (2) pemegang hak pengelolaan; (3) nazir, untuk tanah wakaf; (4) pemilik tanah bekas milik adat; (5) masyarakat hukum adat; (6) pihak yang menguasai tanah negara dengan iktikad baik; (7) pemegang dasar penguasaan atas tanah; dan/atau (8) pemilik 
bangunan, tanaman, atau benda lain yang berkaitan dengan tanah.

Para pemilik tanah dengan status tanah bekas milik adat (tidak bersertifikat) diakui oleh peraturan perundang-undangan pengadaan tanah jo. Undang-Undang Nomor 5 Tahun 1960 tentang Peraturan Dasar Pokok-Pokok Agraria (Buku Kedua, Ketentuan-Ketentuan tentang Konversi, Pasal II ayat (1)). Bukti kepemilikan atas tanah bekas milik adat yang diakui adalah: "(1) petuk pajak bumi/landrente, girik, pipil, ketitir, verponding Indonesia atau alat pembuktian tertulis dengan nama lainnya, sebagaimana diatur dalam Pasal II, VI, dan VII Ketentuan Konversi Undang-Undang Pokok Agraria; (2) akta pemindahan hak yang dibuat di bawah tangan yang dibubuhi tanda kesaksian oleh kepala adat, lurah, kepala desa atau nama lain yang dibuat sebelum berlakunya Peraturan Pemerintah Nomor 10 Tahun 1961 tentang Pendaftaran Tanah dengan disertai alas hak yang dialihkan; (3) surat tanda bukti hak milik yang diterbitkan berdasarkan Peraturan Swapraja yang bersangkutan; (4) surat keputusan pemberian hak milik dari pejabat yang berwenang baik sebelum atau sejak berlakunya Undang-Undang Pokok Agraria; (5) surat keterangan riwayat tanah yang pernah dibuat oleh Kantor Pelayanan Pajak Bumi dan Bangunan disertai dengan alas hak yang dialihkan" (Pasal 21 ayat (2) huruf a, b, c, d, dan e Perpres Nomor 71 Tahun 2012).

Putusan a quo tidak melihat fakta bahwa para penggugat telah tinggal di wilayah Bukit Duri secara turun-temurun sejak tahun 1940-an. Para penggugat memiliki tanah dengan dasar kepemilikan tanah berupa verponding Indonesia, surat jual beli di bawah tangan, dan Akta Jual Beli Notaris diakui oleh Pasal 21 ayat (2) Perpres Nomor 71 Tahun 2012 jo. Ketentuan Konversi
Pasal II ayat (1) Undang-Undang Pokok Agraria jo. Pasal 24 ayat (1) huruf j Peraturan Pemerintah Nomor 24 Tahun 1997 tentang Pendaftaran Tanah. Tergugat mengakui atas kepemilikan tanah para penggugat. Pengakuan ini dicantumkan dalam dokumen amdal proyek normalisasi (PUPR BBWSCC, 2015: 1-32).

Aspek lain yang perlu diperhatikan dalam putusan a quo adalah Undang-Undang Pengadaan Tanah dan Perpres Nomor 71 Tahun 2012 memberikan perlindungan hukum, jaminan hak untuk mendapatkan penggantian yang layak, serta memberikan prioritas utama kepada para pemegang hak atas tanah. Undangundang dan Perpres ini memberikan sarana untuk menilai, memeriksa keberatan, mengadili, dan memutuskan keberatan warga melalui pengadilan tata usaha negara atas segala bentuk keberatan dari para pemilik tanah. Undangundang ini menyeimbangkan antara kebutuhan pembangunan untuk kepentingan umum dengan kebutuhan masyarakat untuk mendapatkan haknya. Undang-undang ini memberikan kepastian hukum dan tahap-tahap pengadaan tanah yang terukur, transparan, dan akuntabel dalam proses pengakuan hak atas tanah, dan pemberian ganti kerugian yang layak kepada para pemegang hak atas tanah.

Undang-Undang Pengadaan Tanah jo. Perpres Nomor 71 Tahun 2012 jo. UndangUndang Pokok Agraria telah memberikan jaminan kepastian hukum (Ismail, 2012) bagi para penggugat. Putusan a quo yang mengatakan bahwa para penggugat tidak ada yang memiliki sertifikat hak milik atas tanah telah melanggar prinsip asas kepastian hukum dan asas legalitas. Status tanah tidak bersertifikat tetap dilindungi oleh Undang-Undang Pokok Agraria, UndangUndang Pengadaan Tanah, dan Perpres Nomor 
71 Tahun 2012. Tanah-tanah para penggugat yang tidak bersertifikat tetap mempunyai hak untuk mendapatkan penggantian yang layak.

Putusan a quo telah melanggar prinsip asas kepastian hukum karena pertimbangan majelis hakim banding tidak merujuk pada peraturan perundang-undangan yang berlaku, tidak berdasarkan pada kepatutan yang hidup di dalam masyarakat, dan melanggar prinsip keadilan bagi para penggugat. Kebijakan penggusuran tanpa mengikuti tata cara yang diatur dalam Undang-Undang Pengadaan Tanah dan Perpres Nomor 71 Tahun 2012, jelas melanggar prinsip asas kepastian hukum dan merupakan tindakan inkonstitusional karena Pasal 1 ayat (3) UUD NRI 1945 jelas menegaskan "negara Indonesia adalah negara hokum.”

Kebijakan yang ditetapkan dalam Perda Nomor 1 Tahun 2012 jo. Pergub Nomor 163 Tahun 2012 jo. Kepgub Nomor 2181 Tahun 2014 dan dokumen perencanaan proyek normalisasi kali Ciliwung adalah pengadaan tanah, dilakukan dengan mengacu pada peraturan perundangundangan tentang pengadaan tanah.

Berdasarkan pada kebijakan tersebut di atas, putusan a quo melanggar prinsip asas legalitas. Merujuk pada pendapat Stahl, unsur pertama negara berdasarkan pada hukum adalah terpenuhinya jaminan hak asasi warganya. Melalui putusan a quo jaminan hak para penggugat atas tanah-tanahnya, dan jaminan untuk mendapatkan kompensasi atas tanah dan bangunannya telah dilanggar oleh negara. Negara secara sadar melalui institusi Pengadilan Tinggi Tata Usaha Negara dan Pemda Jakarta secara bersama-sama melakukan pelanggaran prinsip asas legalitas, dan melanggengkan tindakan pemerintah berdasarkan kekuasaan (machstaat).
Pelanggaran prinsip ini dilakukan karena mereka secara bersama-sama telah melanggar hak asasi para penggugat untuk diakui kepemilikan tanahnya, dan diberikan kompensasi atas hak milik tanahnya.

Putusan a quo jelas melanggar prinsip ketiga negara hukum menurut Stahl, yaitu pemerintah dalam menjalankan fungsi eksekutif harus bersumber pada hukum. Dimaksud dengan bersumber pada hukum adalah segala tindakan pemerintah harus berdasarkan pada hukum positif, kepatutan yang tumbuh dalam masyarakat, adat istiadat, dan etika moral. Kebijakan pelaksanaan program ini harus berdasarkan pada peraturan pengadaan tanah. Tetapi pelaksanaan kebijakan itu justru bertentangan dengan kebijakan yang telah ditetapkan sebelumnya. Kebijakan penggusuran jelas bertentangan dengan peraturan perundang-undangan pengadaan tanah, sehingga dapat disimpulkan kebijakan Pemda Jakarta dan putusan a quo melanggar asas legalitas.

Putusan a quo sebagai lembaga peradilan administrasi negara justru melanggar prinsip kepastian hukum, prinsip legalitas, dan prinsip pengelolaan administrasi negara yang baik. Putusan a quo telah menyebabkan ketidakpastian hukum administrasi negara, hukum tanah, dan hukum pengadaan tanah. Putusan a quo telah melanggengkan tata kelola pemerintahan berdasarkan pada prinsip negara kekuasaan (machstaat).

\section{KESIMPULAN}

1. Putusan a quo yang mengatakan bahwa "penerbitan SP 3 tidak bertentangan dengan peraturan perundang-undangan dan asas-asas umum penyelenggaran pemerintahan yang baik" merupakan 
sebuah pertimbangan yang tidak tepat. Karena penertiban itu bertentangan dengan asas kepastian hukum dan bertentangan dengan Undang-Undang Administrasi Pemerintahan, Undang-Undang Pokok Agraria dan Undang-Undang Pengadaan Tanah. Penertiban itu merupakan perbuatan melawan hukum.

2. Putusan a quo tidak dapat memberikan perlindungan hukum pada para pemilik tanah, karena Undang-Undang Pokok Agraria dan Undang-Undang Pengadaan Tanah memberikan perlindungan hukum kepada masyarakat untuk memilik tanah. Semua jenis hak atas tanah tetap dilindungi dan dapat diberikan penggantian atau kompensasi hak atas tanah. Status tanah tidak bersertifikat tetap dilindungi oleh Undang-Undang Pokok Agraria, UndangUndang Pengadaan Tanah, dan Perpres Nomor 71 Tahun 2012. Tanah-tanah para penggugat yang tidak bersertifikat tetap mempunyai hak untuk mendapatkan penggantian yang layak.

\section{DAFTAR ACUAN}

Azhary. (1995). Negara hukum Indonesia, analisis yuridis normatif tentang unsur-unsurnya. Jakarta: UI Press.

Erwiningsih, W. (2009). Pelaksanaan pengaturan hak menguasai negara atas tanah menurut UUD 1945. Jurnal Hukum, 118(Edisi Khusus), 118136.

Hadjon, P.M. et al. (2015). Pengantar hukum administrasi Indonesia. Yogyakarta: Gadjah Mada University Press.
Hakim, L. (2011, Juni). Kewenangan organ negara dalam penyelenggaraan pemerintahan. Jurnal Konstitusi, IV(1), 103-130.

Humah, D. (2007). Cita-cita negara hukum di Indonesia: Studi tentang pembuatan tambahan penjelasan UUD 1945 \& Piagam HAM oleh MPRS pada masa transisi orde baru 19661968. Ternate: Elkaf.

Indroharto. (1993). Usaha memahami UndangUndang tentang Peradilan Tata Usaha Negara (1). Jakarta: Sinar Harapan.

Ismail, N. (2012, Januari-April). Arah politik hukum pertanahan \& perlindungan kepemilikan tanah masyarakat. Jurnal RechtsVinding, 1(1), 33-51.

Kementerian Pekerjaan Umum dan Perumahan Rakyat - Balai Besar Wilayah Sungai Ciliwung Cisadane [PUPR - BBWSCC]. (2015, Maret). Dokumen analisis dampak lingkungan proyek normalisasi kali Ciliwung. Jakarta: PUPR BBWSCC.

Mahfud MD. Moh. (2006). Membangun politik hukum, menegakkan Konstitusi. Cetakan Pertama. Jakarta: LP3ES.

Sirajuddin \& Winardi. (2015). Dasar-dasar hukum tata negara Indonesia. Malang: Setara Press.

Soemarwi, V.W.S. (2017a). Politik hukum rusunawa dalam penggusuran paksa warga Bukit Duri. Studi kasus: Rusunawa Rawabebek. Jakarta: Yayasan Ciliwung Merdeka.

(2017b). Tinjauan normatifempiris asas partisipatif dalam perencanaan pembangunan kota: Normalisasi kali Ciliwung di Bukit Duri. Jakarta: SNRM.

Sugiono, B., \& Husni MD, A. (2000). Supremasi hukum \& demokrasi. Jurnal Hukum, 7(14), 7182. 
Suseno, F.M. (1987). Etika politik: Prinsip-prinsip moral dasar kenegaraan modern. Jakarta: PT Gramedia.

Syafiie, I.K., Tandjung, D., \& Modeong, S. (1999). Ilmu administrasi publik. Jakarta: PT Rineka Cipta.

Weber, M. (2019). Economy \& society: A new translation. Tribe, K. (Ed.). Cambridge: Harvard University Press.

Wijk, H.D. (1984). Van, hoofdstukken van administratief recht. Vuga: S-Gravenhage. 